\title{
PENGARUH PENDIDIKAN KESEHATAN CERAMAH TERHADAP TINGKAT PENGETAHUAN REMAJA TENTANG KESEHATAN REPRODUKSI DI SMP NEGERI 2 TANJUNGSARI SUMEDANG
}

\author{
${ }^{1}$ Delli Yuliana, ${ }^{2}$ Iyos Sutisna \\ ${ }^{1,2}$ Program Studi DIII Keperawatan \\ Universitas Pendidikan Indonesia Kampus Sumedang \\ J1. Mayor Abdul Rahman No.211 Kotakaler Sumedang Utara Sumedang Telp. (0261) 201244 \\ Jl. Margamukti No. 93 Licin Cimalaka Sumedang 45353 Telp. / Fax. (0261) 203084 / 205172 \\ Email:Delli_imoet@yahoo.co.id
}

\begin{abstract}
Abstrak
Latarbelakang : Salah satu masalah utama yang dialami remaja adalah masalah kesehatan reproduksi. Hal ini didukung data SDKI (2012) yang menyatakan secara nasional terjadi peningkatan angka remaja yang melakukan hubungan seksual pranikah yaitu sekitar 9,3\% atau sekitar 3,7\%. Hal ini akan berdampak meningkatnya masalah reproduksi remaja misalkan kehamilan yang tidak diinginkan, aborsi, penyakit menular seksual (PMS), serta kekerasan seksual. Berdasarkan latar belakang diatas, perlu dilakukan pendidikan kesehatan untuk mengingkatkan pengetahuan remaja terkait kesehatan reproduksi remaja. Menurut beberapa penelitian sebelumnya pendidikan kesehatan terbukti efektif untuk meningkatkan pengetahuan. Adapun tujuannya yaitu untuk mengetahui pengaruh pendidikan kesehatan terhadap tingkat pengetahuan remaja tentang kesehatan reproduksi. Metode Penelitian : Rancangan penelitian ini menggunakan eksperimen semu (Quasi exsperimen), dengan pendekatan pre test dan post tes. Jumlah sampel dari masing-masing baik kelompok intervensi maupun kontrol sebanyak 22 responden, teknik pengambilan sampel secara purposive sampling, instrumen dalam penelitian ini dengan menggunakan kuesioner. Pelaksanaan penelitian dilaksanakan ke dalam tiga tahap yaitu tahap persiapan pelaksanaan dan tahap evaluasi, analisis data menggunakan uji statistik $t$ test independent dan dependen. Hasil penelitian terdapat perbedaan yang bermakna pada pengetahuan tentang kesehatan reproduksi sebelum dan setelah dilakukan pendidikan keseahatan ceramah pada kelompok intervensi $(\mathrm{P}=0.036)$, tidak terdapat perbedaan pada kelompok kontrol $(\mathrm{p}=0.162)$. Kesimpulan Pendidikan kesehatan dengan metode ceramah dapat meningkatkan pengetahuan remaja tentang kesehatan reproduksi.
\end{abstract}

Kata kunci : Pendidikan kesehatan dan Kesehatan Reproduksi.

\begin{abstract}
Background: One of the main problems teenagers experience is reproductive health issues. This is supported by data of the SDKI (2012) which states nationally an increase in the number of adolescents who have premarital sexual intercourse is about $9.3 \%$ or about $3.7 \%$. This will result in increased adolescent reproductive problems such as unwanted pregnancy, abortion, sexually transmitted diseases (PMS), and sexual violence. Based on the above background, it is necessary to do health education to improve adolescent knowledge related to adolescent reproduction health. According to some previous studies health education has proven to be effective for improving knowledge. The purpose is to determine the effect of health education on the level of adolescent knowledge about reproductive health. Research Method: This research design uses quasi experiment (Quasi exsperimen), with pre test and post test approach. The number of samples from each intervention and control group are 22 respondents, the sampling technique is purposive sampling, the instrument in this study by using questionnaire. Implementation of the research carried out into three stages of the preparation phase of implementation and evaluation phase, data analysis using independent and dependent $t$ test statistics. The results showed that there was a significant difference in the knowledge of reproductive health before and after the lecture education in the intervention group $(P=0.036)$, there was no difference in the control group $(p=0.162)$. Conclusion Health education with lecture methods can improve adolescent knowledge about reproductive health.
\end{abstract}

Keywords: Health education and Reproductive Health. 


\section{PENDAHULUAN}

Hasil penelitian Survey Demografi dan Kesehatan Indonesia (SDKI) tahun 2012 menunjukkan bahwa sebagian besar remaja mendapatkan informasi kesehatan dari televisi sebanyak $85 \%$. Hal ini akan berpengaruh terhadap perkembangan remaja, remaja cenderung akan meniru apa yang dia lihat dan dengar. Apabila informasi tersebut positif akan berpengaruh positif, tetapi apabila informasi yang didapat negatif maka akan menimbulkan masalah kesehatan bagi remaja. Hal ini sesuai dengan data BKKBN (2012) yang menunjukan bahwa pengetahuan remaja perempuan tentang masa subur baru mencapai $29 \%$ sedangkan pengetahuan laki laki sebesar $32,2 \%$. Pengetahuan remaja perempuan dan laki-laki tentang resiko kehamilan sebelum nikah mencapai 49,5\% dan 45,5\%. Sebesar $34,7 \%$ remaja perempuan dan $30,9 \%$ remaja laki-laki yang berusia 14-19 tahun mengatakan mempunyai teman dekat dan pernah melakukan hubungan seksual sebelum menikah. Data (SDKI) tahun 2012 tentang komponen Kesehatan Reproduksi Remaja, yang menunjukkan bahwa secara nasional terjadi peningkatan angka remaja yang pernah melakukan hubungan seksual pranikah yaitu sekitar 9,3\% atau sekitar 3,7 juta remaja.

Masa remaja awal mempunyai resiko tinggi melakukan hubungan seksual pranikah. Oleh karena itu, masa yang paling tepat untuk memberikan pendidikan kesehatan reproduksi adalah pada masa remaja awal. Pendidikan kesehatan merupakan salah satu cara yang efektif untuk meningkatkan pengetahuan remaja tentang kesehatan reproduksi. Pendidikan kesehatan dapat dilakukan dengan beberapa metode, salah satu metode pendidikan kesehatan yang dapat digunakan yaitu metode ceramah. Ceramah adalah pidato yang disampaikan oleh pembicara didepan sekelompok pendengar, metode ini baik untuk sarana yang berpendidikan tinggi maupun berpendididkan rendah (Notoatmojo, 2011). Metode ceramah merupakan cara penyajian materi pembelajaran melalui penuturan secara lisan. Keunggulannya dari metode tersebut adalah baik diterapkan pada sasaran yang berpendidikan tinggi maupun rendah, tidak memperlukan persiapan yang rumit cukup menyiapkan ruang kelas serta tempat duduk untuk audien kegiatan sudah bisa dilaksanakan.

Hasil penelitian Yuliana, dkk (2014) menunjukkan bahwa pendidikan kesehatan dengan metode ceramah efektif dapat meningkatkan pengetahuan siswa sekolah dasar tentang kebersihan gigi dan mulut. Hal ini juga didukung dari penelitian Frantin, dkk (2015) menyatakan bahwa ada pengaruh pendidikan kesehatan metode ceramah tentang reproduksi remaja terhadap peningkatan pengetahuan dan sikap Siswa SMP Negeri 08 Belitung. Hasil penelitian tersebut sejalan dengan hasil penelitian Rijal (2015) yang menyatakan bahwa terdapat pengaruh antara pendidikan kesehatan metode ceramah tentang kesehatan reproduksi remaja terhadap peningkatan pengetahuan dan sikap tentang perilaku seksual pada remaja di SMP Negeri 2 Galur Kulon Progo.

Berdasarkan hasil studi pendahuluan yang telah dilakukan oleh peneliti terhadap 12 siswa, 6 orang mengaku sudah pernah berpacaran, dan didukung dengan aktivitas mereka tentang aktivitas pacaran yaitu bergandengan tangan dan berciuman. Sedangkan 6 orang lainnya mengaku belum pernah berpacaran, dan tidak mengetahui kesehatan reproduksi. Sebagian besar Pengetahuan siswa tentang reproduksi manusia didapatkan dari pelajaran biologi, belum ada pendidikan kesehatan yang diadakan secara khusus tentang kesehatan reproduksi remaja di sekolah ini. 


\section{METODE PENELITIAN}

Jenis penelitian menggunakan eksperimen semu (Quasi exsperimen) dengan rancangan pre test dan post test nonequivalent control group. Sampel yang digunakan dalam penelitian ini sebanyak 22 responden pada siswa dan siswi di SMP Negeri 2 Tanjungsari.
Teknik pengambilan sampel dalam penelitian ini adalah dengan menggunakan teknik purposive sampling. Instrumen yang digunakan yaitu dengan menggunakan kuesioner terkait pengetahuan kesehatan reproduksi. Sedangkan analisis bivariat menggunakan paired sample t test.

\section{HASIL PENELITIAN}

Tabel 1.

Distribusi Frekuensi Karakteristik Responden pada Kelompok Intervensi dan Kelompok Kontrol

\begin{tabular}{lcccc}
\hline \multirow{2}{*}{ Karakteristik } & \multicolumn{4}{c}{ Kelompok } \\
\cline { 2 - 5 } & \multicolumn{2}{c}{ Intervensi (n 22) } & \multicolumn{2}{c}{ Kontrol (n 22) } \\
\cline { 2 - 5 } & \multicolumn{1}{c}{ F } & \% & F & \% \\
\hline Jenis Kelamin : & & & & \\
Laki-laki & 3 & 13.64 & 2 & 9.09 \\
Perempuan & 19 & 86.36 & 20 & 90.91 \\
\hline
\end{tabular}

Berdasarkan tabel 1, dapat dijelaskan bahwa jumlah laki-laki pada kelompok intervensi 13.64\% lebih banyak daripada jumlah laki-laki kelompok kontrol 9.09\%. Sedangkan jumlah perempuan kelompok intervensi $86.36 \%$ lebih sedikit daripada jumlah perempuan pada kelompok kontrol $90.91 \%$.

Tabel 2.

Perbedaan skor Pengetahuan responden sebelum dan sesudah Pendidikan Kesehatan Ceramah tentang Kesehatan Reproduksi Remaja pada Kelompok Intervensi dan Kelompok Kontrol di SMP Negeri 2 Tanjungsari Sumedang Desember 2016

\begin{tabular}{clcccc}
\hline Variabel & & N & Mean & Std. Deviation & P \\
\hline Intervensi & Sebelum & 22 & 94.37 & 6.8 & \\
& Sesudah & 22 & 97.2 & 4.3 & .036 \\
Kontrol & Sebelum & 22 & 84.85 & 7.9 & .162 \\
& Sesudah & 22 & 84.00 & 7.5 & \\
\hline
\end{tabular}

Paired Sample T-Test

Berdasarkan Tabel 2. menunjukkan bahwa nilai $\mathrm{p}=0.036(\mathrm{p}<0.05)$, dapat dijelaskan bahwa terdapat perbedaan pengetahuan tentang kesehatan reproduksi pada kelompok intervensi, sedangkan pada kelompok kontrol menunjukan bahwa nilai $\mathrm{p}=0.162(\mathrm{p}<0.05)$ sehingga pada kelompok kontrol tidak ada perbedaan pengetahuan. 


\section{PEMBAHASAN}

Hasil penelitian menunjukkan bahwa terdapat peningkatan rata-rata skor pengetahuan antara sebelum diberikan pendidikan kesehatan 94,37 dan sesudah diberikan pendidikan kesehatan sebesar 97,2. Hasil uji statistik dengan menggunakan paired Samples menunjukkan $\quad \mathrm{p}$-value $=0.036 \quad(\mathrm{p}<0,05)$ sehingga dapat disimpulkan bahwa terdapat pengaruh pendidikan kesehatan Ceramah terhadap peningkatan pengetahuan remaja tentang kesehatan reproduksi.

Pendidikan kesehatan merupakan suatu proses perubahan prilaku yang dinamis dengan tujuan mengubah atau mempengaruhi perilaku manusia yang meliputi komponen pengetahuan, sikap, ataupun praktik yang berhubungan dengan tujuan hidup sehat baik secara individu, kelompok maupun masyarakat, serta merupakan komponen dari program kesehatan. Dalam penyampaian pendidikan kesehatan terhadap masyarakat, terdiri dari 3 (tiga) metode yaitu metode pendidikan individual, metode pendidikan kelompok dan metode pendidikan masa (Notoatmodjo, 2012).

Pendidikan kesehatan yang dilakukan dalam penelitian ini yaitu menggunakan metode/ teknik ceramah (metode pendidikan kelompok) hal tersebut dikarenakan metode ceramah merupakan metode yang sangat efektif untuk semua sasaran baik yang berpendidikan tinggi maupun berpendidikan rendah. Dalam penyampaian materi peneliti menggunakan alat bantu yaitu materi yang sudah disiapkan oleh peneliti dengan menggunakan media power point yang sudah dilengkapi dengan gambar-gambar terkait kesehatan reproduksi.

Hasil penelitian Zioleny, et al. (2000) menyatakan bahwa pemanfaatan media dalam penyampaian informasi dapat meningkatkan ketertarikan dan pemahaman materi lebih baik pada anak-anak. Hal tersebut berhubungan dengan tahap perkembangan kognitif anak usia sekolah dimana dalam periode tersebut anak mulai mampu melakukan proses berfikir terhadap suatu kejadian dan tindakan yang mereka lihat secara nyata, Hockenberry dan Wilson (2007, sebagaimana dikutip dalam Potter dan Perry, 2010).

Hasil Frantin, dkk (2015) menyatakan bahwa ada pengaruh pendidikan kesehatan reproduksi remaja terhadap peningkatan pengetahuan dan sikap Siswa SMP Negeri 08 Belitung. Hasil penelitian tersebut sejalan dengan hasil penelitian Rijal Syamsur (2015) yang menyatakan bahwa terdapat pengaruh antara pendidikan kesehatan kesehatan reproduksi remaja terhadap peningkatan pengetahuan dan sikap tentang perilaku seksual pada remaja di SMP Negeri 2 Galur Kulon Progo. Hal ini didukung oleh penelitian Nasution (2012) yang menyatakan bahwa ada pengaruh pengetahuan tentang kesehatan reproduksi remaja terhadap perilaku seksual pranikah remaja di Indonesia.

Dilihat dari beberapa hasil penelitian yang sudah dilakukan sebelumnya,pendidikan kesehatan terbukti dapat meningkatkan pengetahuan seseorang. Pius (sebagaimana dikutip dalam kamus bahasa Indonesia, 2001) menyatakan bahwa pengetahuan merupakan proses belajar baik formal maupun informal yang melibatkan panca indra seseorang. Dalam hal ini pengetahuan merupakan domain yang sangat penting untuk terbentuknya sebuah perilaku seseorang (overt behaviour).

Hasil penelitian Sarah, et al (2013) di Pakistan pengetahuan mempunyai pengaruh terhadap peningkatan perilaku. Hasil penelitian tersebut didukung oleh beberapa penelitian menyebutkan bahwa perilaku yang 
didasarkan oleh pengetahuan akan lebih langgeng daripada perilaku yang tidak didasari oleh pengetahuan. Dengan demikian pengetahuan merupakan dasar bagi seseorang untuk merubah perilaku kesehatan yang lebih baik. Pengetahuan tentang kesehatan reproduksi remaja penting untuk disampaikan terhadap remaja, mengingat remaja adalah periode dimana terjadinya perubahan ciri-ciri penampilan dan fungsi fisiologis, terutama yang berhubungan dengan organ reproduksi, sedangkan dari sisi psikologis, masa remaja merupakan saat individu mengalami perubahan dalam aspek kognitif, emosi, sosial, dan moral, serta masa remaja merupakan masa peralihan dari masa anakanak menuju kedewasaan (Kusmiran E, 2011).

Pengetahuan kesehatan reproduksi remaja penting untuk disampaikan kepada remaja, jika seorang remaja tidak disertai pengetahuan yang cukup dan dengan emosi yang masih belum stabil maka hal tersebut dapat mengakibatkan efek yang negatif terhadap remaja itu sendiri, seperti ancaman terhadap kesehatan alat reproduksi remaja, aborsi, penyakit menular seksual, penyalahgunaan obat-obatan terlarang dan lain lain.

Menurut teori Piaget kemampuan kognitif remaja termasuk ke dalam tahap formal operasional, dimana tingkah laku yang ditampilkan oleh remaja adalah rasa kritis segala hal harus rasional dan jelas, sehingga remaja sering mempertanyakan kembali aturan-aturan yang diterimanya, rasa ingin tahu yang merangsang adanya kebutuhan atau kegelisahan akan sesuatu yang harus dipecahkan, dan jalan pikiran egosentris yang berkaitan dengan penentangan terhadap pendapat atau pola pikir orang lain yang tidak sejalan dengan pola pikir diri sendiri. Maka seorang remaja sangat penting diberikan suatu informasi yang benar khususnya tentang kesehatan reproduksi remaja, karena seorang remaja sangat rentan terpengaruh oleh hal-hal negatif dibandingkan hal-hal positif karena faktor sarana dan prasarana yang sudah mendukung sekarang ini seperti televisi, radio dan jaringan internet yang dapat dengan mudah di akses oleh para remaja.

Hasil penelitian ini tidak sejalan dengan penelitian Septiana (2014) menunjukkan bahwa pendidikan kesehatan tentang kesehatan reproduksi tidak berpengaruh terhadap peningkatan pengetahuan remaja SMP Islam Ruhama Ciputat. Hasil penelitian Septiana (2014) sejalan dengan penelitian Istichomah (2004) yang berjudul pengaruh pendidikan kesehatan tentang hipertensi kehamilan terhadap pemeliharaan tekanan darah pada ibu hamil di Puskesmas Pundong Bantul didapatkan hasil bahwa tidak ada pengaruh pendidikan kesehatan tentang hipertensi kehamilan terhadap terpeliharanya tekanan darah ibu hamil. Menurut Tana (2004, dalam Nurfitrianie 2008) menyatakan bahwa berbagai faktor yang memungkinkan dapat berpengaruh pada pendidikan kesehatan adalah pemberi materi, media penyuluhan, serta sasaran yang akan diberikan intervensi.

Media dalam pemberian pendidikan kesehatan ceramah penting untuk di perhatikan mengingat media merupakan alat untuk menyampaikan materi yang akan disampaikan kepada responden. Dalam menyiapkan media penyuluhan penting kita sebagai pemberi materi menyiapkan media sesuai dengan usia perkembangannya, sehingga materi yang disampaikan sesuai tujuan yang diharapkan. Selain itu, pemberi materi disarankan dapat meningkatkan keberagaman metode, sebab penggunaan metode tunggal sepanjang kegiatan diperkirakan akan menurunkan tingkat perhatian responden. 
Keberhasilan suatu pendidikan kesehatan sangat ditentukan oleh pemberi materi dan media yang digunakan. Pemberi materi harus lebih keatif dalam menyampaikan materi, harus mengetahui tahap perkembangan responden, serta menyiapkan media dengan menarik, sehingga diharapkan materi dapat tersampaikan sesuai dengan tujuan yang diharapkan.

\section{PENUTUP}

\section{Kesimpulan}

Terdapat pengaruh pendidikan kesehatan ceramah tentang kesehatan reproduksi terhadap peningkatan pengetahuan remaja.

\section{Saran}

Perlu dikembangkan pendidikan kesehatan ceramah dilingkungan sekolah, dengan menambilkan media yang lebih kreatif, karena menurut penelitian pendidikan kesehatan terbukti dapat meningkatkan pengetahuan remaja.

\section{DAFTAR PUSTAKA}

Darma, K. 2011. Metodologi Penelitian Keperawatan : Panduan Melaksanakan dan Menerapkan Hasil Penelitian. Jakarta: Trans Info Media.

Frantin F. K, dkk. 2015. Pengaruh Promosi Kesehatan Reproduksi Remaja terhadap Pengetahuan dan Sikap Siswa SMP Negeri 08 Belitung. Politeknik Kemenkes Manado. Jurnal Ilmiah Bidan.

Istichomah. 2004. Pengaruh Pendidikan Kesehatan tentang Hipertensi Kehamilan terhadap Pemeliharaan Tekanan Darah Ibu Hamil di Puskesmas Pundong Bantul.
Yogyakarta: Jurnal Kesehatan Surya Medika.

Kusmiran E. 2011 . Kesehatan Reproduksi Remaja dan Wanita. Jakarta: Salemba Medika.

Notoatmodjo. 2012. Promosi Kesehatan dan Perilaku Kesehatan. Jakarta: Rineka Cipta.

Notoatmodjo. 2012. Promosi Kesehatan di Sekolah: Jakarta: Rineka Cipta.

Nasotion, Lilestina. 2012. Pengaruh Pengetahuan tentang Kesehatan Reproduksi Remaja terhadap Perilaku Seksual Pranikah di Indonesia. Jakarta: Pusat Penelitian dan Pengembangan KB dan Keluarga Sejahtera. BKKBN.

Pius. 2001. Ilmu Sosial Dasar. Bandung: Refika Aditama.

Potter dan Perry. 2010. Fundamental of Nursing: Fundamental keperawatan: Buku 1: Edisi 7. Jakarta: Salemba Medika.

Rijal. 2015. Pengaruh Pemberian Pendidikan

Kesehatan Reproduksi terhadap pengetahuan dan Sikap tentang perilaku seksual pada remaja di SMP Negeri 2 Galur Kulon Progo. Yogyakarta: Naskah Publikasi.

Septiana. 2014. Pengaruh Pendidikan Kesehatan terhadap Tingkat Pengetahuan Remaja tentang Kesehatan Reproduksi di SMP Islam Ruhuma Ciputat. Skripsi. Tidak Dipublikasikan.

Survei Demografi dan Kesehatan Indonesia. 2012. Kesehatan Reproduksi Remaja. Diunduh 20 November 2016, dari http://www. Kesga.kemkes.go.id.

Yuliana, Sekarwana, dan Susanti. 2014. Pengaruh Edukasi Sebaya terhadap 
Pengetahuan, Sikap dan Tindakan Kebersihan Gigi Dan Mulut pada Anak Usia Sekolah di Sekolah Dasar Negeri Kebon Hui Kecamatan Tanjungsari Kabupaten Sumedang. Tesis. Universitas Padjadjaran: Bandung. Tidak Dipublikasikan.
Zioleny, R., Kimzeke, G., Stakic, S., Bruyn, M.D., et al (2000). Peer education training of trainers manual: Youth peer education elektronik resources. Diunduh 24 November 2016, dari http://www.aidsmark.org/ipc.en/pdf. 